\title{
BAIAP2 Gene
}

National Cancer Institute

\section{Source}

National Cancer Institute. BAIAP2 Gene. NCI Thesaurus. Code C24258.

This gene plays a role in neuronal growth regulation. 